\title{
Effect of Estrogen on Yolk Deposition and Atresia of Ovarian Follicles in Hypophysectomized Hens
}

\author{
Tadashi Nakada ${ }^{1)}$, Liu Asato ${ }^{2)}$, Takuro Oikawa ${ }^{1)}$, \\ Zuiko KoJA $^{1)}$ and Kousaku TANAKA ${ }^{3)}$ \\ ${ }^{1)}$ Faculty of Agriculture, \\ ${ }^{2)}$ Faculty of Medicine, University of the Ryukyus, Okinawa 903-01 and \\ ${ }^{3)}$ Faculty of Agriculture, Kyushu University, Fukuoka-shi 812
}

Estradiol-17 $\beta$ was injected into hypophysectomized hens immediately after, and at 8 and $16 \mathrm{~h}$ after hypophysectomy and the incidence of yolk deposition in the largest (F1), the second largest (F2) and the third largest (F3) follicles of the ovary at various times up to $23 \mathrm{~h}$ after the hypophysectomy was estimated by the uptake of Sudan dye. The incidence of follicular atresia was also checked at the same time. The results indicate that the yolk deposition lasts longer in the estrogen-treated hens than in hens treated with no estrogen, and that the incidence of atresia was lower in the estrogen-treated hens. It is suggested that estrogen maintains yolk deposition and delays the incidence of atresia in the absence of pituitary hormones as far as the three largest follicles are concerned.

(Jpn. Poult. Sci., 31 : 162-167, 1994)

Key words : hypophysectomy, yolk deposition, estradiol-17 $\beta$, Sudan III.

\section{Introduction}

Yolk deposition in the ovarian follicle of the hen is stimulated by the gonadotrophin, Follicle Stimilating Hormone; FSH (STURKIE, 1976), secreted from the pituitary.

Estrogen, secreted from the ovary by the action of the pituitary gonadotrophin (HuANG et al., 1979), enhances the synthesis of yolk precursors by the liver (STURKIE, 1976), and causes the elevation of blood level of the yolk precursors (STURKIE, 1976), but it is known as not to stimulate by itself the yolk deposition in the ovarian follicle, because its injection into immature pullets (STURKIE, 1954) or into nonlaying hens (STURKIE, 1954) did not cause any appreciable growth of the follicle.

Estradiol-17 $\beta$ (E2) is a major estrogen in the hen (GILBERT, 1971) and is produced by theca cells of the follicle (Huang et al., 1979 ; Marrone and Hertelendy, 1983). The production of E2 is more prominent in the second largest follicle (F2) than in the first (F1) and the third (F3) follicles (SHAнABr et al., 1975). In granulosa cells of the follicle, there exist receptors for estrogen and their specific binding changes with the growth (weight increase) of F1 and F2 during a period of preovulatory 24 hours of an egg laying cycle (КАMIYOSH et al., 1986). The existence of estrogen receptors in the follicle indicates that estrogen may have a direct action inside of the follicle, and the relation- 
ship between the specific binding of estrogen receptor and the weight increase lead us to assume that estrogen itself has a certain role for the deposition of yolk into the follicle. In hypophysectomized hens, the ovarian follicular atresia usually occurs some 12 hours after hypophysectomy, but larger follicles existing in the ovary are maintained by an administration of FSH (OPEL and NALBANDOv, 1961). Information on whether estrogen has an inhibitory or stimulatory effect for causing atresia is completely lacking. The present experiments were performed to demonstrate the effect of estrogen on the yolk deposition and on the incidence of atresia in the ovary of the hen in which the influence of pituitary gonadotrophins are eliminated by hypophysectomy.

\section{Materials and Methods}

White Leghorn hens (24 month-old; $1.8-2.0 \mathrm{~kg}$ body wt) laying $3-4$ eggs in a regular sequence with a 1-day pause between sequences were used. They were housed in individual cages under $14 \mathrm{~h}(05: 00-19: 00 \mathrm{~h})$ light per day with feed and water given ad libitum. In these hens, oviposition of the terminal egg of the sequence occurred at about $14: 00 \mathrm{~h}$, and ovulation of the first ovum (C1) of the next sequence usually occurred at about $07: 00 \mathrm{~h}$. Hypophysectomy was performed 6-7 h after oviposition of the terminal egg, i.e., approximately $10 \mathrm{~h}$ before $\mathrm{C} 1$ ovulation. Procedures for the hypophysectomy were the same as reported earlier (TANAKA and NoBUKUnI, 1977). Into the hypophysectomized hens, estradiol-17 $\beta$ (Sigma) which was dissolved in sesame oil was injected intramuscularly immediately after and at 8 and $16 \mathrm{~h}$ after the hypophysectomy. The dose of injection was $5 \mathrm{mg}$ per hen and the volume of injection was $0.5 \mathrm{ml}$. Emulsion of Sudan III (Merck) was prepared by the method of W ARREN and CONRAD (1939) and injected intravenously with the volume of $5 \mathrm{~m} l$ (dose : approximately $2 \mathrm{mg} / \mathrm{hen}$ ) at various times after the hypophysectomy. The hens were killed $2 \mathrm{~h}$ after the single injection of Sudan III. The time of autopsy was at a $2 \mathrm{~h}$ interval from 9 to $23 \mathrm{~h}$ after the hypophysectomy. After confirming the completeness of the hypophysectomy, the largest (F1), the second largest (F2) and the third largest (F3) follicles of the ovary were excised and examined under naked eyes for the dying of the yolk with Sudan III following the removal of the follicular wall and also for the incidence of atresia. Data were analyzed for the significance of difference by Wald test according to CATMOD procedure of SAS statistic package (ROBINSON and ETCHES, 1986).

\section{Results}

Table 1-1 shows the incidence of deposition of dyed yolk in the largest (F1), the second largest (F2) and the third largest (F3) follicles of the ovary of hypophysectomized hens into which Sudan dye was injected. Analysis of variance of data (Table $1-2)$ revealed a highly significant difference $(\mathrm{P}<0.001)$ between estradiol $-17 \beta$ (E2) treatment and nontreatment, between follicles of different size, and between times of observation. In hens treated with E2, the deposition of dyed yolk was observed up to $23 \mathrm{~h}$ after hypophysectomy, although the percentage of follicle possessing dyed yolk showed a decrease at $15 \mathrm{~h}$ and thereafter in F1, at $21 \mathrm{~h}$ and thereafter in F2, and at 17 
$\mathrm{h}$ and thereafter in F3. In hens not treated with E2, the deposition of dyed yolk was oberved up to $17 \mathrm{~h}$ in $\mathrm{F} 1$, and up to $19 \mathrm{~h}$ in $\mathrm{F} 2$ and $\mathrm{F} 3$. A decrease in the percentage of the number of dyed yolk was observed at $11 \mathrm{~h}$ and thereafter in F1 and F3, and at $15 \mathrm{~h}$ and thereafter in F2.

Table 1-1. Incidence of deposition of dyed yolk ${ }^{1}$ in the largest (F1), the second largest (F2) and the third largest (F3) follicles of the ovary of hypophysectomized hens treated or not treated with estradiol $-17 \beta(\mathrm{E} 2)^{2}$

\begin{tabular}{|c|c|c|c|c|c|c|c|c|}
\hline \multirow{3}{*}{$\begin{array}{l}\text { Hours after } \\
\text { hypophy- } \\
\text { sectomy }\end{array}$} & \multicolumn{4}{|c|}{ Hens treated with E2 } & \multicolumn{4}{|c|}{ Hens not treated with E2 } \\
\hline & \multirow{2}{*}{ No. } & \multicolumn{3}{|c|}{ Dyed yolk (\%) } & \multirow{2}{*}{ No. } & \multicolumn{3}{|c|}{ Dyed yolk (\%) } \\
\hline & & $\mathrm{F} 1$ & $\mathrm{~F} 2$ & F3 & & $\mathrm{F} 1$ & $\mathrm{~F} 2$ & F3 \\
\hline 9 & 5 & 100 & 100 & 100 & 5 & 100 & 100 & 100 \\
\hline 11 & 7 & 100 & 100 & 100 & 7 & 87 & 100 & 100 \\
\hline 13 & 5 & 100 & 100 & 100 & 5 & 60 & 100 & 80 \\
\hline 15 & 8 & 75 & 100 & 100 & 8 & 50 & 88 & 75 \\
\hline 17 & 6 & 67 & 100 & 83 & 6 & 17 & 67 & 67 \\
\hline 19 & 6 & 67 & 100 & 83 & 6 & 0 & 33 & 13 \\
\hline 21 & 6 & 33 & 83 & 67 & 6 & 0 & 0 & 0 \\
\hline 23 & 7 & 29 & 71 & 71 & 7 & 0 & 0 & 0 \\
\hline
\end{tabular}

${ }^{1}$ Dye (Sudan III ; about $2 \mathrm{mg} / 5 \mathrm{ml} /$ hen) was injected intravenously $2 \mathrm{~h}$ before the indicated time after hypophysectomy.

${ }^{2} \mathrm{E} 2(5 \mathrm{mg} / 0.5 \mathrm{ml} / \mathrm{hen})$ was injected intramuscularly immediately after, and at 8 and $16 \mathrm{~h}$ after hypophysectomy.

Table 1-2. Analysis of variance for the data shown in Table 1-1

\begin{tabular}{lcc}
\hline Source & DF & Chi-Square \\
\hline Treatment & 1 & $41.12^{* * *}$ \\
Follicle & 2 & $26.01^{* * *}$ \\
Time & 7 & $63.36^{* * *}$ \\
\hline
\end{tabular}

${ }^{* * *} \mathrm{P}<0.001$

The incidence of follicular atresia and its analysis of variance are shown in Tables 2-1 and 2-2, respectively. In hens treated with E2, the atresia was not observed until $15 \mathrm{~h}$ after hypophysectomy in F1, until $21 \mathrm{~h}$ in F2, and until $17 \mathrm{~h}$ in F3. In hens not treated with E2, the atresia was observed earlier than in hens treated with E2 in all the three follicles, although the time of apearance differed among the follicles : at $11 \mathrm{~h}$ in $\mathrm{F} 1,17 \mathrm{~h}$ in $\mathrm{F} 2$, and $13 \mathrm{~h}$ in $\mathrm{F} 3$. 
Table 2-1. Incidence of follicular atresia in the largest (F1), the second largest (F2) and the third largest (F3) follicles of the ovary of hypophysectomized hens treated or not treated with estradiol-17 $\beta(\mathrm{E} 2)^{1}$

\begin{tabular}{|c|c|c|c|c|c|c|c|c|}
\hline \multirow{3}{*}{$\begin{array}{l}\text { Hours after } \\
\text { hypophy- } \\
\text { sectomy }\end{array}$} & \multicolumn{4}{|c|}{ Hens treated with E2 } & \multicolumn{4}{|c|}{ Hens not treated with $\mathrm{E} 2$} \\
\hline & \multirow{2}{*}{ No. } & \multicolumn{3}{|c|}{ Atresia } & \multirow{2}{*}{ No. } & \multicolumn{3}{|c|}{ Atresia } \\
\hline & & F1 & $\mathrm{F} 2$ & F3 & & $\mathrm{F} 1$ & $\mathrm{~F} 2$ & F3 \\
\hline 9 & 5 & 0 & 0 & 0 & 5 & 0 & 0 & 0 \\
\hline 11 & 7 & 0 & 0 & 0 & 7 & 14 & 0 & 0 \\
\hline 13 & 5 & 0 & 0 & 0 & 5 & 40 & 0 & 20 \\
\hline 15 & 8 & 25 & 0 & 0 & 8 & 50 & 0 & 25 \\
\hline 17 & 7 & 29 & 0 & 13 & 7 & 71 & 21 & 21 \\
\hline 19 & 6 & 33 & 0 & 17 & 6 & 100 & 67 & 83 \\
\hline 21 & 6 & 67 & 17 & 17 & 6 & 100 & 100 & 100 \\
\hline 23 & 7 & 71 & 14 & 30 & 7 & 100 & 100 & 100 \\
\hline
\end{tabular}

${ }^{1}$ Same as in Table 1-1

Table 2-2. Analysis of variance for the data shown in Table 2-1

\begin{tabular}{lcc}
\hline \hline Source & DF & Chi-Square \\
\hline Treatment & 1 & $47.73^{* * *}$ \\
Follicle & 2 & $23.87^{* * *}$ \\
Time & 7 & $62.02^{* * *}$ \\
\hline
\end{tabular}

${ }^{* * *} \mathrm{P}<0.001$

\section{Discussion}

Deposition of dyed yolk in the three largest follicles, F1, F2 and F3 of the ovary of hens was shown to occur after hypophysectomy with or without estradiol-17 $\beta$ (E2) treatment (Table 1-1). The finding that dyed yolk deposition occurred in the hypophysectomized hens not treated with E2 suggests that the deposition of yolk in the ovarian follicle is possible to occur even in the absence of pituitary gonadotrophin and that the follicular yolk deposition may be continued somewhat spontaneously for a while after hypophysectomy. The treatment with E2 was found to prolong the period of the yolk deposition after hypophysectomy. The effect of E2 may be caused by mainly a direct action of $\mathrm{E} 2$ on the follicles, because estrogen receptors are reported to be present in the hen ovcarian follicle (KAMIYoshi et al. 1986). Estrogen stimulates the vitellogenin production by the liver (STURKIE, 1976) and causes an elevation of plasma concentration of yolk precursors (STURKIE, 1976). Therefore, the effect of E2 in the prolongation of the yolk deposition might be partly due to the effect on the plasma concentration of yolk precursors if the permeability of the ovarian follicular and granulosa membranes were sustained after hypophysectomy.

The stimulatory effect of E2 on the dyed yolk deposition was higher in both F2 and $\mathrm{F} 3$ than in F1, of which hens were killed later than $15 \mathrm{~h}$ after hypophysectomy. The 
cause of the E2 effect is not clear at present. However, the fact that dye has been well deposited in the smaller sizes of follicles than in F1 without E2 treatment after hypophysectomy (Table 1-1) could be accounted for a high content of follicular E2 in the smaller sizes (Robinson and ETChes, 1986 : ShahABi $e t$ al., 1975). Thus it is suggested that E2 may facilitate dye deposition into the follicles.

The $\mathrm{E} 2$ treatment was also found to be effective in preventing the incidence of atresia of F1, F2 and F3 to be caused by hypophysectomy (Table 2-1). The suppressing effect of $\mathrm{E} 2$ for the follicular atresia appears to be reciprocal to the stimulatory effect for the follicular dyed yolk deposition (Table 1-1). The reciprocal relationship between the effects of $\mathrm{E} 2$ suggests that there exists a certain relationship between the deposition of yolk and the incidence of atresia in the ovarian follicles of the hen. How estrogen concerns in the follicular atresia needs further investigation.

\section{Acknowledgement}

The authors wish to express their sincere thanks to Dr. Katsuhide TANAKA of Tokyo University of Agriculture, for his critical reading for the manuscript.

\section{References}

GilberT, A.B. (1971) The endocrine ovary in reproduction, in Physiology and Biochemistry of the Domestic Fowl vol.3. (Bell, D.J. and B.M. FreEman, eds.) 1449-1464. Academic Press. London, New York.

HuANG, E.S., K.J. KAO and A.V. NALBandov (1979) Synthesis of sex steroids by cellular components of chicken follicles, Biology and Reprodution, 20, 454-462.

KamiYoshI, M., T. NiwA and K. TANAKA (1986) Nuclear estrogen receptor bindings in granulosa cells and estradiol-17 $\beta$ contents in follicular membranes of the ovary of the hen during the ovulatory cycle, General and Comparative Endocrinology, 61:428-435.

MARRONE, B.L. and F. HERTLENDY (1983) Steroid metabolism by avian ovarian cells during follicular maturation, Biology and Reproduction, 29 : 953-962.

OpeL, H. and A.V. NALBandov (1961) Onset of follicular atresia following hypophysectomy of the laying hen, Proceeding Society of Experimental Biology and Medicine, $107: 233-235$.

RoBinson, F.E. and R.J. ETches (1986) Ovarian steroidgenesis during follicular maturation in the hen, (Gallus domesticus). Biology and Reproduction, 35 : 1096-1105.

SAS (1986) SAS/STAT User's Guid (Release 6. 03). SAS Inst., Inc., Cary, NC. USA.

Shahabi, N.A., H.W. NoRTon and A.V. NALBANDOv (1975) Steroid levels in follicles and the plasma of hens during the ovulatory cycle, Endocrinology, $96: 962-968$.

StURKIE, P.D. (1954) Avian Physiology. Ist ed. 247-284. Cornell University press. Ithaca, New York.

StURKIE, P.D. (1976) Avian Physiology. 3rd ed. 302-330. Springer-Verlag. New York. Heidelberg Berlin.

TANAKA, K. and K. NoBUKUni (1977) A stereotaxic device for hypophysectomy of the domestic fowl, Japanese Journal of Zootechnical Science, $48: 532-537$.

W ARREN, D.C. and R.R. CONRAD (1939) Growth of the hen's ovum, Journal of Agricultural Science, $58: 875-893$. 


\title{
下垂体除去鵎におりる卵胞の卵黄蓄積と閉鎖に対する エストロジェン投与の効果
}

\author{
仲田 正 ${ }^{1)} \cdot$ 安里 龍 ${ }^{2)} \cdot$ 及川 卓郎 ${ }^{1)}$ \\ 古謝 瑞幸1) \\ 1)琉球大学農学部生物生産学科 \\ ${ }^{2)}$ 琉球大学医学部保健学科, 沖綶県西原町 903-01. \\ 3)九州大学農学部畜産学科, 福岡市東区箱猗 812
}

産卵嗂の下垂体を除去して, 除去直後, 8 時間後及び 16 時間後にエストラジオール $17 \beta$ を投与し, 下垂体除 去後 23 時間までのいろいろな時間における卵巣中の最 大卵胞 (F1)，第 2 卵胞 (F2)，第 3 卵胞 (F3) の卵黄蓄 積の有無をスダン色素の取り込みによって判定した。ま た同時に，これらの卵胞について卵胞閉鎖の有無を観察 した。その結果，エストラジオール投与鷄では無投与䳕 よりも卵黄の蓄積が F1，F2，F3 ともに下垂体除去後長 い時間継続すること，またこれらの卵胞が閉鎖する率も
長い時間低いことが明らかとなった。従って, エストロ ジェンは下垂体ホルモンの関与なしに卵巣中の大卵胞に おける卵黄の蓄積を維持させるとともに, これらの卵胞 の閉鎖を遅延させる作用を示するのであると推察され る。

(家会会誌, $31: 162-167,1994)$ キーワート : 下垂体除去, 卵黄蓄積, エストラジオールー $17 \beta$, スダン III 